\title{
PENINGKATAN PEMAHAMAN MASYARAKAT MENGENAI COVID-19 MENGHADAPI NEW NORMAL DI CIBEBER CILEGON BANTEN
}

\author{
Aida Nur Sabrina ${ }^{1}$, Rr Rintis Hadiani², Zainal Arifin³, Syamsul Hadi \\ 1 Teknik Kimia Fakultas Teknik Universitas Sebelas Maret \\ 2Teknik Sipil Fakultas Teknik Universitas Sebelas Maret \\ ${ }^{3}$ Teknik Mesin Fakultas Teknik Universitas Sebelas Maret
}

syamsulhadi@ft.uns.ac.id

\begin{abstract}
Abstrak
Kuliah Kerja Nyata merupakan bentuk pengabdian mahasiswa kepada masyarakat sebagai salah satu bentuk dari Tridharma Perguruan Tinggi. Kegiatan ini rutin dilaksanakan oleh Universitas Sebelas Maret dua kali dalam setahun, yaitu pada bulan Januari-Febuari dan Juli-Agustus. Pada periode kali ini kegiatan Kuliah Kerja Nyata UNS dilaksanakan di Cibeber Cilegon Banten tidak dilaksanakan seperti biasanya dikarenakan ada pandemi COVID 19, tetapi secara individu di tempat tinggal masing-masing dengan menggunakan metode $90 \%$ daring dan $10 \%$ terjun langsung ke masyarakat. Walaupun informasi bisa ditemukan dengan mudah di internet, penyebaran informasi terkait Coronavirus masih belum merata, kesadaran masyarakat pun masih minim sehingga KKN ini bertujuan untuk meningkatkan pemahaman masyarakat terkait Covid-19, meningkatkan pemahaman dan kesadaran masyarakat tentang Pola Hidup Bersih Sehat (PHBS), serta meningkatkan pengetahuan masyarakat terkait pentingnya mematuhi protokol kesehatan yang berlaku selama masa Pandemi Covid-19.
\end{abstract}

Kata Kunci : Kuliah Kerja Nyata (KKN), Covid-19, Pengabdian Masyarakat, Pemahaman Masyarakat

\section{PENDAHULUAN}

Pandemi COVID-19 diketahui bermula terjadi di kota Wuhan Tiongkok akhir tahun 2019, dan kemudian menyebar ke seluruh dunia di awal tahun 2020 (Guo et al., 2020), termasuk ke Indonesia. Dua orang warga Indonesia yang berdomisili di kota Depok terinfeksi penyakit ini pada tanggal 2 Maret 2020 dua (Djalante et al.,
2020; Martha, 2020). Perkembangan pandemi COVID-19 terus bergulir dan menyerang orangorang yang tidak dapat menjaga jarak (physical and social distancing) (Chen et al., 2020). WHO kemudian menetapkan wabah ini sebagai pandemic pada Maret 2020, seiring semakin banyak negara yang mengalami kasus tersebut (Cucinotta \& Vanelli, 2020; Spinelli \& Pellino, 2020). Hingga saat, 10/08/2020, ini jumlah 
kasus positif COVID 127.083 orang, 82.236 sembuh dan 5.765 orang meninggal.

Semua pihak dituntut untuk bisa beradaptasi dengan situasi ini. Pemerintah pun sudah berusaha melakukan tugasnya dalam menghadapi pandemi ini, diantaranya mendirikan Gugus Tugas Percepatan Penanganan COVID, membuat regulasi baru terkait tempat umum, kendaraan umum, pendidikan secara daring, keringanan kredit dan hal lain di bidang ekonomi serta mengirim bantuan APD dan alat kesehatan lain. Informasi pun bisa diperoleh dengan mudah di Internet. Namun, penyebaran informasi tentang COVID 19 masih belum merata, banyak jarkoman yang menyesatkan dan kesadaran sebagian masyarakat yang masih minim dalam menghadapi COVID 19. Hal inilah yang menjadi tugas masyarakat untuk saling mengingatkan dan menjaga kekompakan dengan saling membantu di tengah masa pandemi.

Dari uraian diatas, melalui program KKN yang diadakan oleh Universitas Sebelas Maret Surakarta (KKN COVID-19) ini, mahasiswa dapat ikut andil dalam peran tersebut untuk mensupport pemahaman masyarakat terhadap COVID-19 di daerah masing-masing, termasuk di Kecamatan Cibeber Kota Cilegon Provinsi Banten sehingga diharapkan masyarakat akan lebih paham dan sadar akan pentingnya mematuhi protokol kesehatan yang telah ada dan bisa memutus rantai penyebaran COVID 19.

\section{METODE}

Metode yang dilakukan dalam kegiatan ini terbagi menjadi 2 kegiatan yaitu bersifat edukasi dan penyerahan bantuan. Edukasi yang dilakukan meliputi: 1. Program Edukasi COVID 19 dan New Normal; 2. Sosialisasi pentingnya menggunakan masker dengan benar; 3. Edukasi mencuci tangan dengan benar; 4. Edukasi online terkait COVID 19 dan new normal melalui grup Whatsapp warga; 5. Penempelan Poster mengenai COVID-19; 6. Edukasi mengenai pembuatan handsanitizer sesuai arahan WHO; dan 7. Program Tetap Produktif \#DiRumahAja;. Sedangkan program pemberian bantuan berupa 1. Pengadaan Alat Cuci Tangan Portable; 2. Program Hidroponik; 3. Program Bimbingan Belajar; dan 4. Program Kerja Bakti dan Penyemprotan Desinfektan.

\section{HASIL DAN PEMBAHASAN}

Program kerja KKN UNS Covid-19 telah dilaksanakan di Cibeber Cilegon dari Juni hingga Juli 2020 dengan program kerja dan hasil sebagai berikut.

\section{Program Edukasi COVID 19 dan New Normal}

Target kualitatif dari program ini adalah adanya peningkatan pemahaman dan kesadaran sedangkan target kuantitatifnya adalah warga dan pengguna sosial media instagram termasuk teman-teman pelaksana pengabdian. Program ini dilaksanakan dalam berbagai kegiatan diantaranya: Edukasi online melalui instagram @relawancovid19_uns.

Materi yang dipaparkan seperti dalam Gambar 1 dalam edukasi online melalui instagram berkaitan dengan COVID 19, New Normal dan pembiasaan positif yang bisa dilakukan di masa pandemi seperti menjaga kesehatan mata di tengah pandemi, tips membeli makan di warung makan dengan aman, peningkatan data penderita COVID 19 yang kian meningkat, protokol olahraga sendiri maupun di luar sesuai dengan peraturan dari kemenkes, protokol VDJ, olahraga yang bisa dilakukan saat pandemi dan lain lain yang bersumber dari kemenkes, WHO dan sumber terpercaya lain. Konten di IG tersebut beberapa bagian merupakan hasil kerjasama kolaborasi dengan beberapa rekan peserta KKN yang lain. Ini menunjukkan bahwa kerjasama tetap bisa dilakukan oleh peserta KKN meskipun berbeda lokasi dan hanya diskusi via online. 


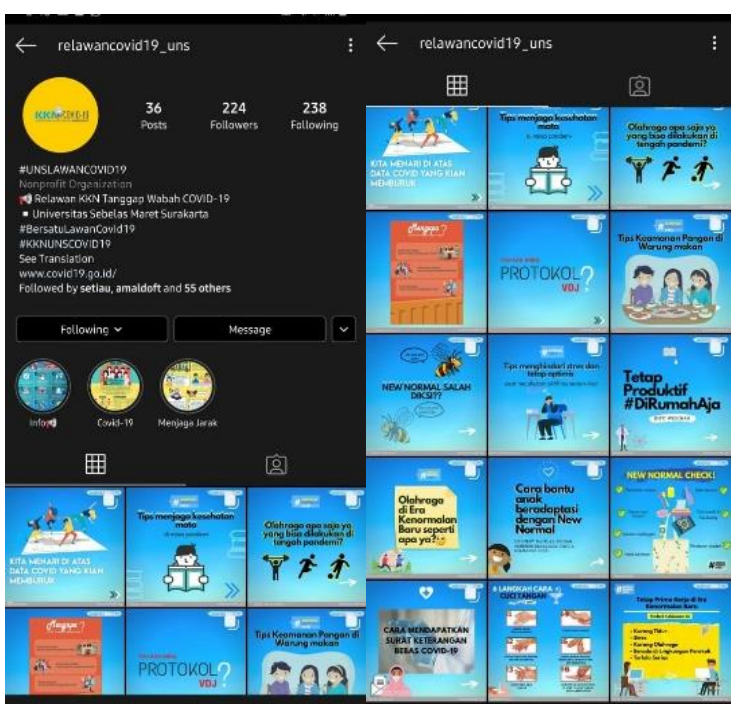

Gambar 1. Instagram @relawancovid19_uns

\section{Sosialisasi Penggunakan Masker}

Kegiatan sosialisasi pentingnya menggunakan masker dengan benar ini dilaksanakan setelah pengajian hari Kamis sore di Balai Warga dengan tujuan untuk meningkatkan kesadaran masyarakat agar tetap menggunakan masker dengan benar saat keluar rumah.

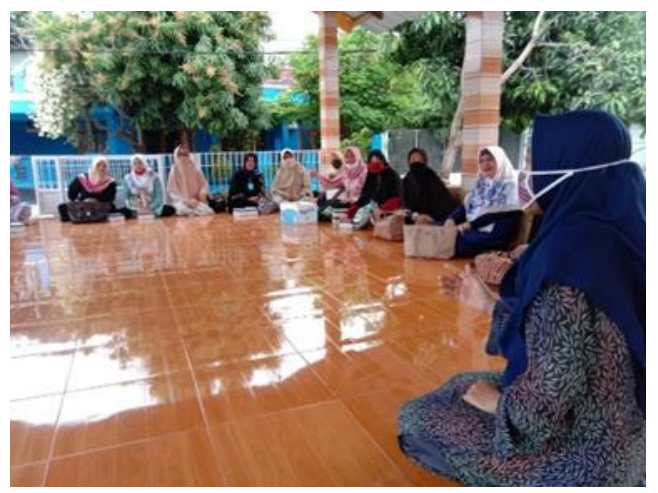

Gambar 2. Sosialisasi pentingnya menggunakan masker dengan benar di balai warga

Kegiatan telah terlaksana dengan lancar dan berhasil ditandai dengan berjalannya diksusi dengan lancar dan dengan banyaknya peserta yang datang dengan tetap menggunakan protokol kesehatan yang berlaku seperti disampaikan di Gambar 2.

\section{Edukasi Mencuci Tangan}

Kegiatan edukasi mencuci tangan dengan benar ini bertujuan untuk mengedukasi warga agar mencuci tangan dengan benar dan selama 20 detik. Edukasi ini dilakukan insidentil bagi warga yang sedang mencuci tangan di tempat cuci tangan portable yang tersedia seperti terlihat di Gambar 3. Kegiatan ini dilaksanakan dalam beberapa kurun waktu tertentu sehingga sangat bermanfaat bagi warga yang secara langsung praktek untuk cara mencuci tangan dengan benar sesuai protokol kesehatan yang diberlakukan.

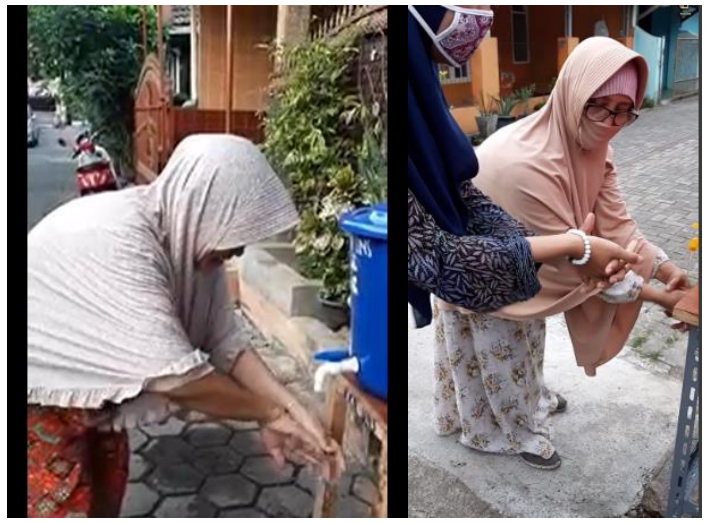

Gambar 3. Edukasi mencuci tangan dengan benar

\section{Edukasi COVID 19 dan new normal}

Kegiatan edukasi online terkait COVID 19 dan new normal dilakukan dengan menggunakan media sosial utamanya melalui grup Whatsapp warga. Materi yang disebar melalui grup Whatsapp merupakan informasi valid yang didapatkan dari website resmi dan terpercaya seperti kemenkes, IDI dan WHO.

Pelaksanaan edukasi online yang dilaksanakan hampir setiap hari tersebut bisa dikatakan berhasil karena banyak respon yang di dapatkan setiap ada postingan tentang topik COVID 19 dan new normal seperti yang disampaikan di Gambar 4. Di Gambar 4 diperlihatkan beberapa postingan dan respon

$$
\text { Lingkungan Hidup dan Bencana }
$$


dari warga masyarakat sehingga diharapkan penyampaian informasi ini dapat meningkatkan kepedulian masyarakat akan pentingnya menjaga kesehatan dan mengikuti protokol kesehatan yang berlaku.

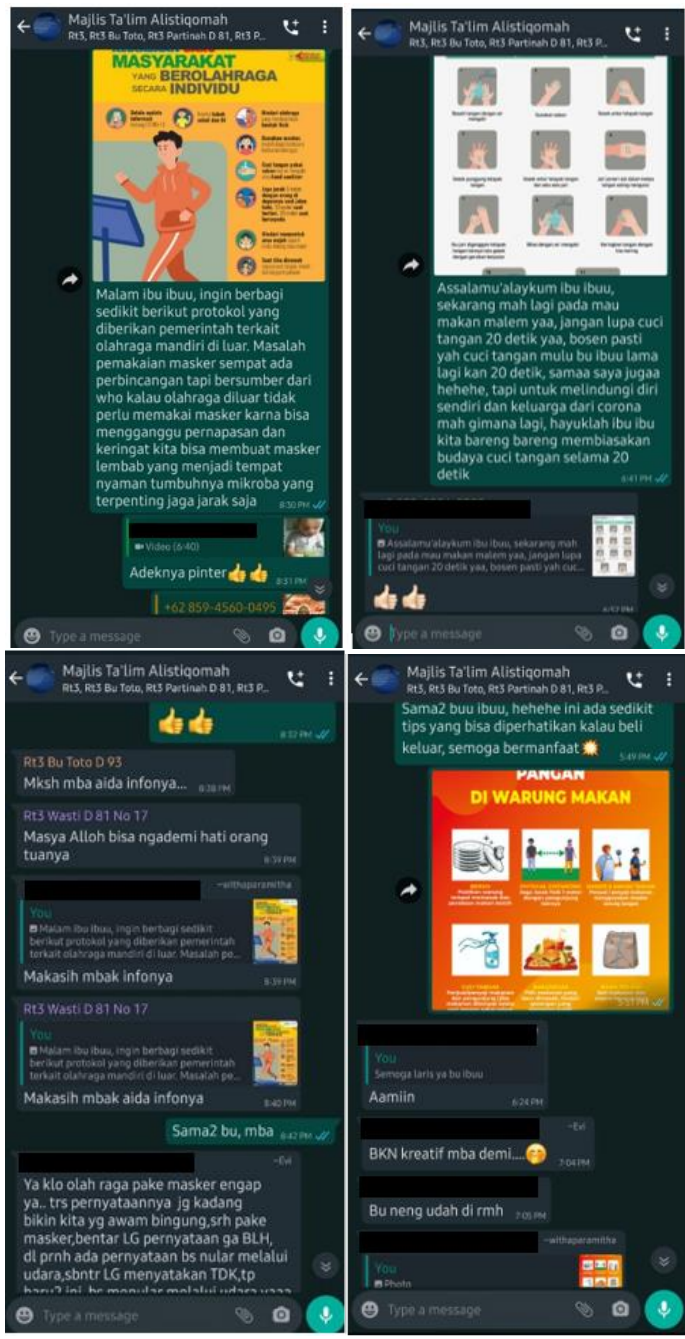

Gambar 4. Penyebaran informasi COVID 19 dan New normal di grup Whatsapp warga

\section{Penempelan Poster mengenai COVID-19}

Upaya lain yang dilaksanakan dalam program KKN untuk meningkatkan kepedulian masyarakat akan pentingnya menjaga kesehatan dan menjalani protokol kesehatan dengan benar adalah Penempelan Poster mengenai COVID-19. Poster ini berisi tentang tanda dan gejala Covid19, cara pencegahan Covid-19, cara menerapkan perilaku hidup bersih \& sehat, serta alternatif jabat tangan secara non-kontak.

Poster-poster tersebut diletakkan di tembok lapangan samping balai warga, karena warga biasa berkumpul di tempat tersebut, sehingga pesan yang disampaikan di poster tersebut akan efektif sampai ke masyarakat yang terbiasa berkumpul di daerah tersebut, lihat Gambar 5.

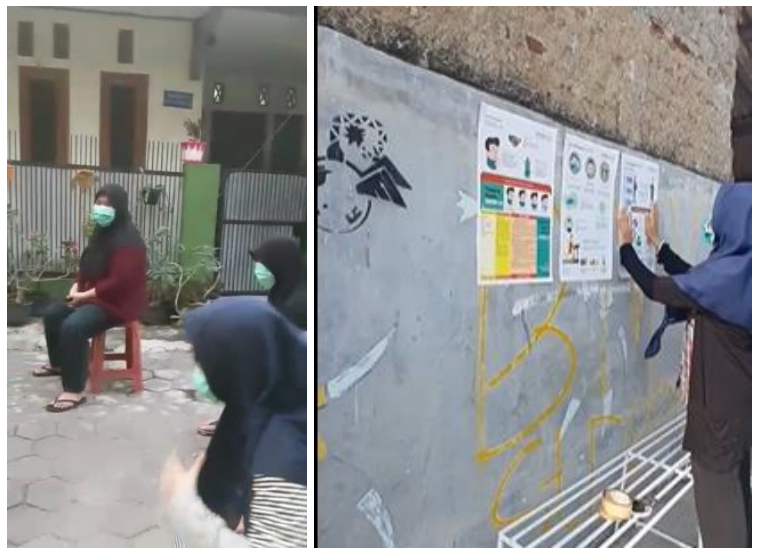

Gambar 5. Penempelan poster di tempat strategis dan edukasi mengenai pembuatan handsanitizer

\section{Edukasi mengenai pembuatan handsanitizer sesuai arahan WHO}

Edukasi ini dilakukan sore hari pada Juli 2020 dan dihadiri oleh warga sekitar. Tujuannya untuk memberikan pemahaman warga tentang kandungan yang ada dalam handsanitizer dan manfaatnya serta cara membuatnya sendiri di rumah, lihat Gambar 5. Proses berljalan lancar dengan hadirnya beberapa warga yang diundang, terjadinya dialog, dan tersampainya materi yang disiapkan oleh pelaksana pengabdian.

\section{Program Tetap Produktif \#DiRumahAja}


Program Tetap Produktif \#DiRumahAja ini memiliki target kualitatif meningkatkan pemahaman dan memberi informasi terkait hal positif yang bisa dilakukan saat pandemic serta membantu anak-anak dalam belajar. Target kuantitatifnya adalah warga Komp. PCI Blok D RT 05 RW 05 termasuk anak-anak dan pengguna media social termasuk teman-teman penulis. Kegiatan yang dilakukan diantaranya memberikan informasi olahraga yang bisa dilakukan saat pandemi dan webinar terkini dengan berbagai macam tema dan topik seperti webinar science direct, digital marketing, enterpreneurship, mindfulness, moderasi beragama serta topik menarik lainnya melalui instagram @relawancovid19_uns seperti disampaikan di Gambar 9.

\section{Pengadaan Alat Cuci Tangan Portable}

Hasil dari angket yang dilakukan oleh pelaksana pengabdian masyarakat menunjukkan bahwa $19 \%$ dari warga belum terbiasa mencuci tangan selama 20 detik dan tempat cuci tangan umum belum tersedia secara merata sehingga dilakukan inisiasi untuk membuat 3 tempat cuci tangan portable berbahan ember sederhana yang diletakkan di tempat warga biasa lewat dan berkumpul beserta infografis tata cara mencuci tangan dengan benar dan selama 20 detik yang dilaminating.

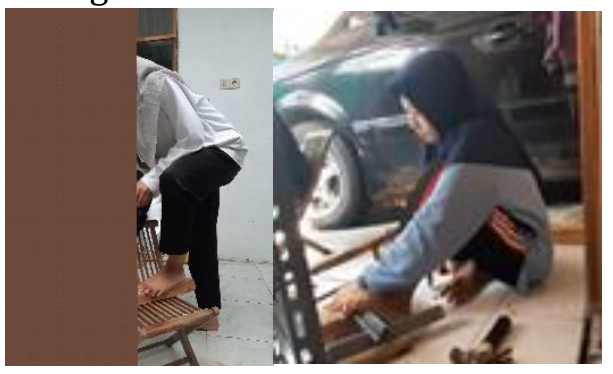

Gambar 6. Proses pembuatan penyangga tempat cuci tangan portable

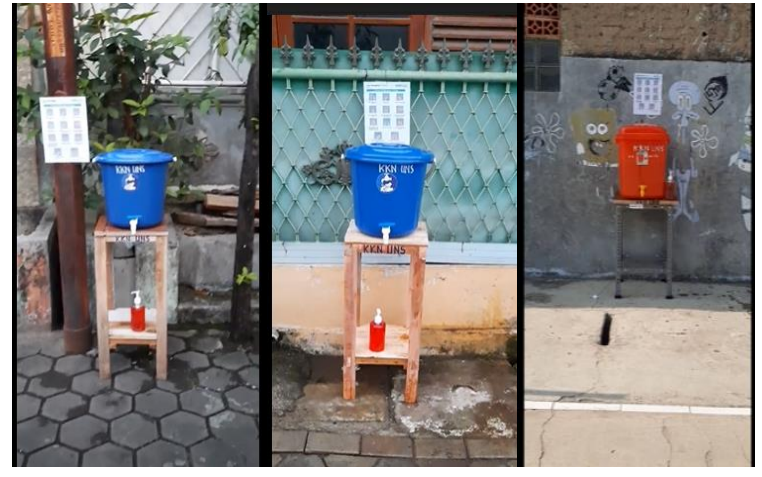

Gambar 7. Tempat cuci tangan portable

Pembuatan dan pemberian tempat cuci tangan portable sudah selesai dilaksanakan. Sambutan masyarakat sangat baik karena donasi ini sesuai dengan kebutuhan masyarakat.

Bahkan untuk pengisian air dilakukan sukarela oleh warga yang rumahnya berdekatan dengan tempat cuci tangan portable tersebut. Tempat cuci tangan portable ini diletakkan di tempat di mana banyak masyarakat mengakses tempat tersebut yaitu di jalan masuk perumahan dan sekolah serta tempat ibadah. Proses pembuatan tempat cuci tangan portable disampaikan di Gambar 6, hasil pembuatan di Gambar 7, sedangkan titik kuning pada Gambar 8 merupakan lokasi peletakkan tempat cuci tangan portable.

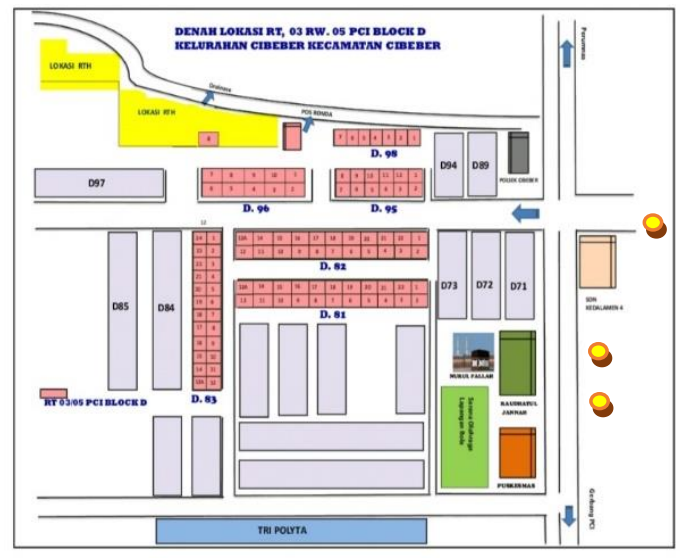

Gambar 8. Titik peletakkan tempat cuci tangan portable 


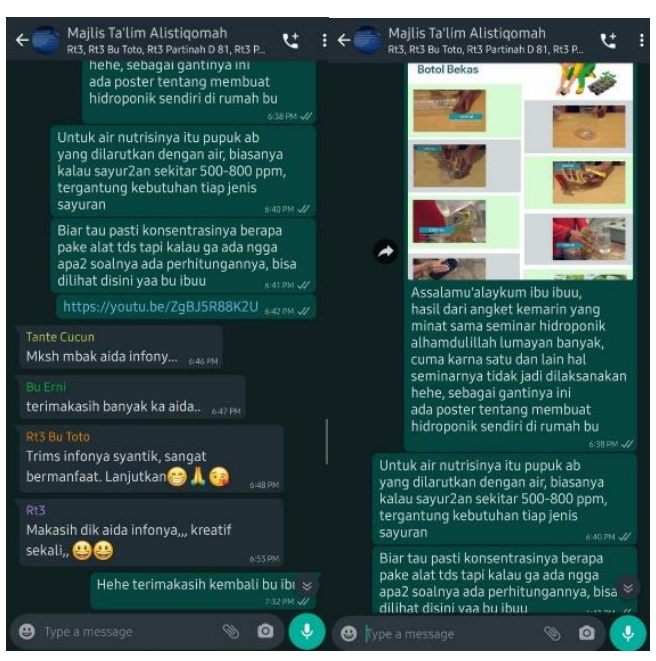

Gambar 10. Penyebaran Informasi terkait Hidroponik

\section{Program Hidroponik}

Program Hidroponik dilakukan dengan membagikan informasi terkait hidroponik sederhana yang bisa dibuat dari botol bekas melalui grup Whatsapp warga. Kegiatan ini sebagai pengganti dari seminar hidroponik yang tidak jadi diadakan dimana berdasarkan hasil angket $78 \%$ warga tertarik untuk mengikutinya, lihat Gambar 10.

\section{Program Bimbingan Belajar}

Kegiatan ini memiliki target anak-anak SD hingga SMA namun ketika pelaksanaan siswa sedang liburan dan baru masuk 2 minggu terakhir sebelum KKN penutupan sehingga hanya 2 siswa yang mengikuti bimbingan belajar dengan mata pelajaran bahasa Inggris dan Matematika. Adapun grup Whatsapp bimbingan belajar tidak jadi dibuat dikarenakan tidak efektif, jadi komunikasi dilakukan melalui japri

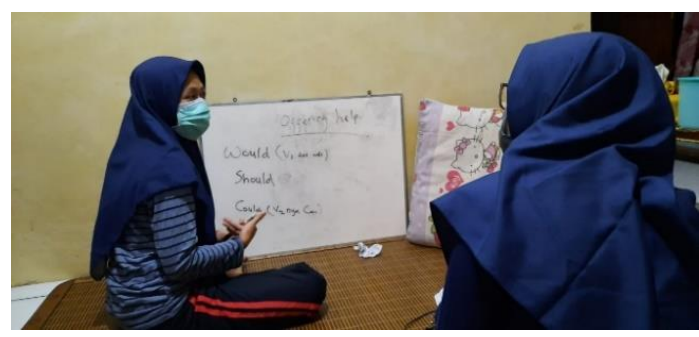

Gambar 11. Bimbingan belajar

\section{Program Kerja Bakti dan Penyemprotan Desinfektan}

Kerja bakti ini dilakukan dengan tujuan meningkatkan kekompakan warga di tengah pandemi dan agar lingkungan di sekitar perumahan bersih serta terhindar dari penyakit, tentunya dengan mengikuti protokol kesehatan dari pemerintah. Setelah kerja bakti, dilakukan pelarutan natrium hipoklorit dengan air dengan perbandingan air : natrium hipoklorit $15 \%$ 1:150 guna penyemprotan desinfektan mengelilingi perumahan agar bisa membunuh virus corona yang mungkin terdapat di pagar rumah ataupun udara sekitar. Kegiatan kerja bakti dan penyemprotan desinfektan ini dilaksanakan oleh bapak-bapak dan pemuda setempat serta penulis dan teman penulis yang sedang melaksanakan KKN seperti disampaikan di Gambar 12.

Kegiatan yang telah dilakukan selama program KKN disosialisasikan melalui media tulis di laman berikut https://www.kompasiana.com/ aida99370/5f36184ed541df5bdf40c603/kkncovid-19-uns-di-daerah-masing-masing\#. Sedangkan video kegiatan belum disampaikan via channel Youtube. Sosialisasi tersebut dilakukan agar semua proses kegiatan KKN dapat selalu dipelajari oleh masyarakat dan bermanfaat terus selama tayangan dan tulisan tersebut dibaca dan ditonton oleh masyarakat luas. 

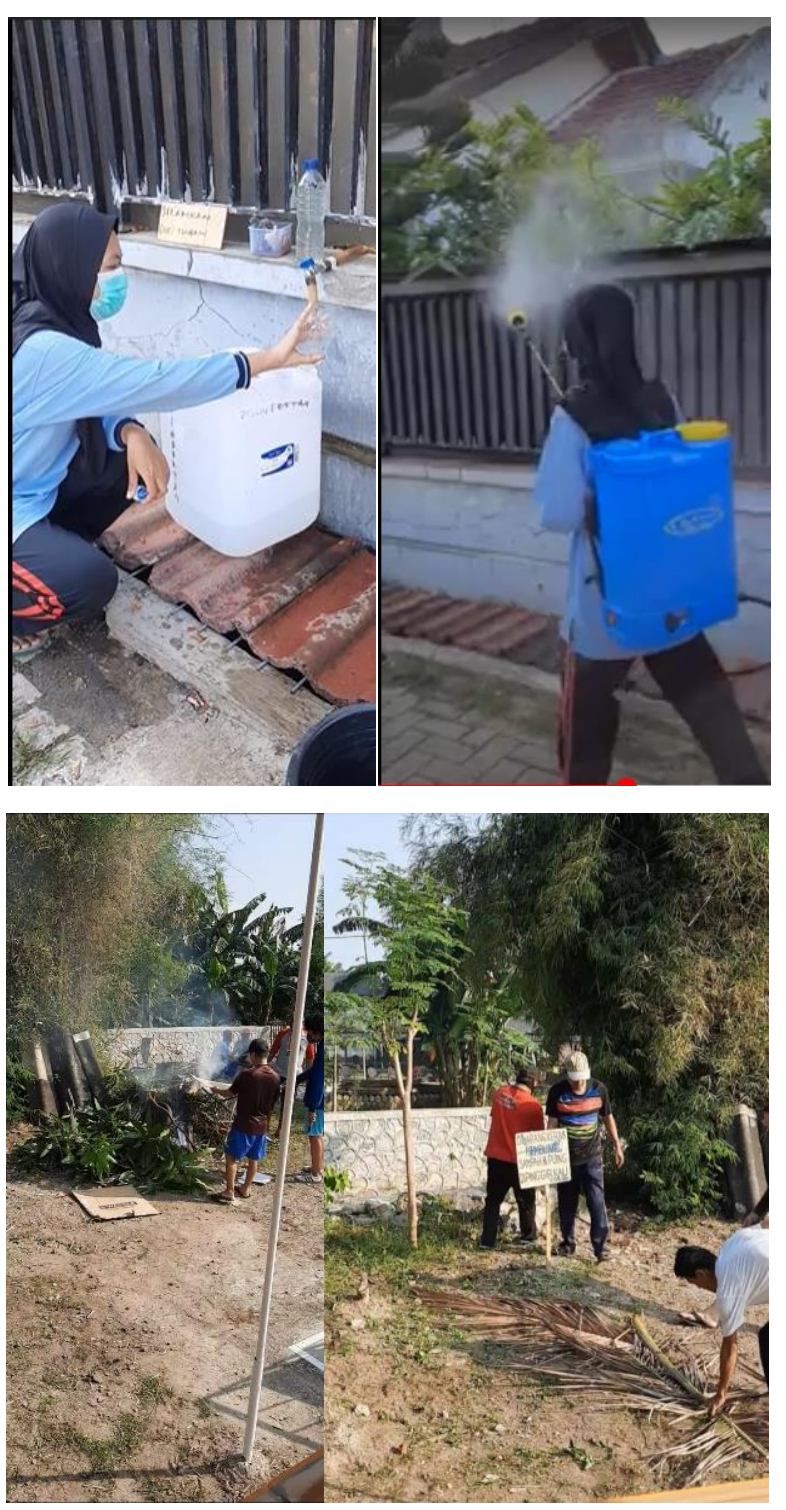

Gambar 12. Kerja Bakti dan Penyemprotan Desinfektan

\section{KESIMPULAN}

Kuliah Kerja Nyata (KKN) COVID-19 telah terlaksana dengan baik dengan melibatkan peran dan berpartisipasi secara aktif mahasiswa dalam masyarakat di tengah masa pandemi di daerah tempat tinggalnya masing-masing. Semua kegiatan yang dilaksanakan pada rentang waktu KKN merupakan suatu rangkaian kegiatan dari program yang sudah direncanakan. Dari kegiatan-kegiatan yang telah terlaksanan dapat diambil kesimpulan mahasiswa KKN dapat hidup bermasyarakat dan memahami realita dalam kehidupan masyarakat dengan menggunakan pengetahuan dan sikap yang dimilikinya, mahasiswa KKN dituntut untuk bersikap kritis dan dapat mencari pemecahan masalah yang ada di masyarakat terutama pada masa pandemi COVID-19, serta mahasiswa KKN dapat menyalurkan ilmu yang telah diperoleh selama masa perkuliahan kepada berbagai lapisan masyarakat.

Mahasiswa KKN UNS sebaiknya harus lebih kreatif, inovatif, dan mempunyai program yang lebih variatif sehingga manfaat yang diberikan kepada masyarakat lebih banyak. Diharapkan juga mahasiswa tidak menganggap bahwa kegiatan ini sebagai suatu beban, melainkan sebagai kegiatan sukarela untuk membantu masyarakat dalam menghadapi masa pandemi, dan dalam melaksanakan program KKN COVID-19, sebaiknya mahasiswa tetap menjaga protokol kesehatan yang ada dan terus melakukan sosialisasi kepada masyarakat.

\section{UCAPAN TERIMAKASIH}

Ucapan terimakasih disampaikan kepada Unit Pengelola KKN LPPM UNS yang telah memberikan kesempatan dan pendanaan untuk melakukan pengabdian kepada masyarakat melalui dana PNBP tahun 2020. Juga kepada masyarakat di Cibeber, Kota Cilegon, Provinsi Banten yang mendukung program KKN berhasil, terkhusus kepada pengurus RT yang telah membimbing dan mengarahkan pelaksanaan KKN sehingga dapat berjalan dengan lancar.

\section{REFERENSI}

Depkes RI. (2006). Perilaku Hidup Bersih dan Sehat di Rumah Tangga. Jakarta: Depkes RI Chen, S., Yang, J., Yang, W., Wang, C., \& Lingkungan Hidup dan Bencana 646 
Bärnighausen, T. (2020). COVID-19 control in China during mass population movements at New Year. The Lancet, 395(10226), 764-766.

Cucinotta, D., \& Vanelli, M. (2020). WHO

declares COVID-19 a pandemic. Acta BioMedica: Atenei Parmensis, 91(1), 157-160.

Djalante, R., Lassa, J., Setiamarga, D., Sudjatma, A., Indrawan, M., Haryanto, B., Mahfud, C., Sinapoy, M. S., Djalante, S., Rafliana, I., Gunawan, L. A., Surtiari, G. A. K., \& Warsilah, H. (2020). Review and analysis of current responses to COVID-19 in Indonesia: Period of January to March 2020. Progress in Disaster Science, 6, 100091.

Guo, Y.-R., Cao, Q.-D., Hong, Z.-S., Tan, Y.Y., Chen, S.-D., Jin, H.-J., Tan, K.-S., Wang, D.-Y., \& Yan, Y. (2020). The Origin, Transmission and Clinical Therapies on Coronavirus Disease 2019 (COVID-19) Outbreak - An Update on the Status. Military Medical Research, 7(11).

Martha, J. (2020). Pemanfaatan Diplomasi Publik oleh Indonesia dalam Krisis
Covid-19. Jurnal Ilmiah Hubungan Internasional, 121-130.

Pikiran Rakyat (2020, Juni 20) Update

Virus Corona di Dunia 20 Juli 2020, Lebih dari 600.000 Orang Tewas akibat Covid-19. Retrieved Agustus 7, 2020 from Pikiran Rakyat : https://www.pikiranrakyat.com/internasional/pr-01615501/updatevirus- corona-di-dunia-20-juli-2020-lebih-dari600000-orang-tewas-akibat-covid-19/ Spinelli, A., \& Pellino, G. (2020). COVID19 pandemic: Perspectives on an Unfolding Crisis. The British Journal of Surgery 107 (7) pp 785-787

Woznitza, N., Hare, S. S., \& Nair, A. (2019). Covid-19 pandemic: Summary of Current and Emerging Issues for Radiographers. https://www.sor.org/news/covid-19-pandemicsummary-current-and-emerging-issuesradiographers. 